\title{
Audit Quality Based on Auditor Features
}

\author{
Zahra Roohbakhsh ${ }^{1 *}$ and Fariba Kazemzadeh ${ }^{2}$
}

1,2 Master of Accounting, Iran.

*Corresponding Author:

\rouhbakhshzahra1970@gmail.com

Received: 15 September, 2021

Accepted: 30 October, 2021

Published: 25 December, 2021

\begin{abstract}
This study aimed to investigate the effect of work experience, professional competence, motivation, accountability and objectivism of the auditor on the quality of audit from the perspective of the employer hired in companies. The present study identified the factors affecting the quality of audit that have not been well studied in Iran. According to the results of this study, the professional competence, accountability and objectivity of the auditor had a significant effect on the quality of audit. Hiring people with great work experience increases the quality of auditing due to the auditor's professional competence. Auditors gain deeper knowledge and better judgment to achieve auditing quality. Accountability improves the auditor's performance and enables them to act objectively without being influenced by the others.
\end{abstract}

Keywords: Auditing quality, Work experience, Professional competence, Motivation, Accountability, Objectivism

\section{Introduction}

Work experience improves the auditor's ability to audit. The work experience affects the amount of time and number of tasks that must be performed by the auditor. Both of these increase the auditor's expertise in auditing. Professional competence includes individual quality, general knowledge and specific skills. Increasing the individual quality, general knowledge and specific skills increases professional competence and provides a higher quality to the auditor. Auditors need motivation for performing their tasks properly. Motivation is an encouragement belonged to auditors who have performance support in trying to achieve their goals. Auditors receive this encouragement from their colleagues or employers. Ramadhens believes that with the motivation, people have high morale to achieve goals and existing standards [1]. Morale allows auditors to complete their work with high attention and consistency (without affecting individual situations on experience) and maintain audit results so that the auditor's work is in accordance with the attached standards and shows the high quality of the auditor's work. The auditor's motivation is divided into four parts, which are: 1 - Character type, specified character type; 2- Internal and external control; 3- Auditor norms, applying rules to the company; 4- Ethical culture in the company: Ethics in the organization is consistent. In performing their duties, auditors definitely strive to meet the standards and thus increase accountability [2]. accountability is defined as a form of psychological encouragement that labels an individual to pay attention to all activities and decisions in the environment. If the auditor has a accountability, then the work is done with the utmost effort and thought so that the auditor completes the audit activity in accordance with the standards. Therefore, the auditor's work will be better and the quality of the audit will be higher [3-5]. Auditors must understand objectivity and must reciprocate the conflict of interest in fulfilling their obligations. Auditors who avoid conflicts of interest, will be able to work fairly and do not tolerate pressure. This consistency indicates that the audit' work quality is high. This study analyzes whether work experience, competency, motivation and objectivism have significant effects on audit quality. 


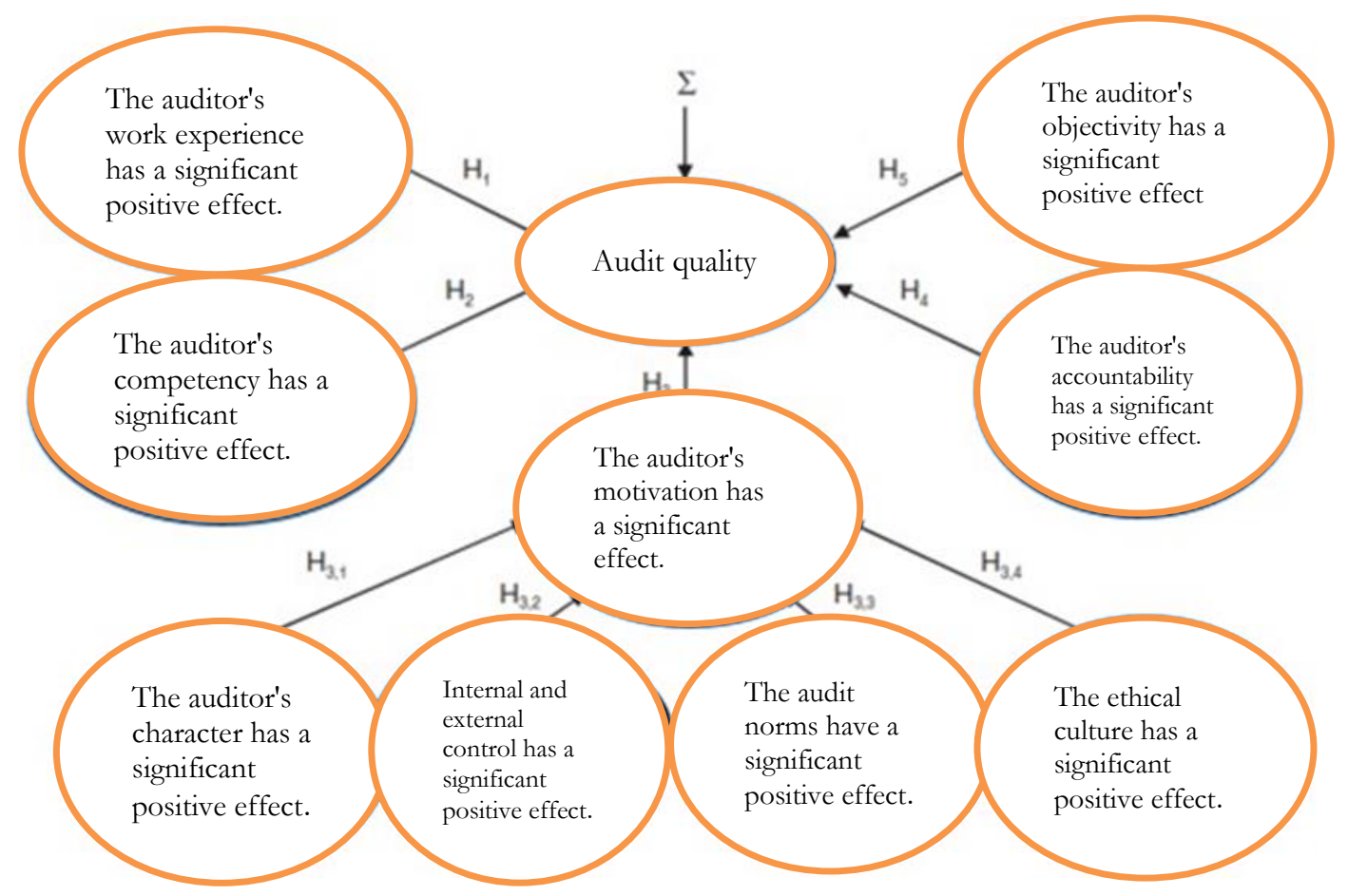

Figure 1. conceptual framework of the study

\section{Thematic Literature Review and Hypothesis Development}

The quality of the audit is the result of the accounting work, which is indicated by a reliable audit report based on certain standards [6]. Audit quality is positively affected by work experience, professional competence, motivation, accountability and objectivism. The study done by Saripudin et al. shows that there is a simultaneous positive effect of independence, experience, professional attention and accountability on audit quality. Ramadhanis found out that professional competence, independence and motivation simultaneously affect the quality of the audit. Research conducted by Samsi et al. shows that work experience, independence, objectivism, integrity and professional competence of auditors simultaneously affect the quality of auditing. Singgih et al. defines work experience as the process of training and enhancing the development of good behavior careers through formal and informal training channels. Samsi states that an employee with high work experience has the benefit of identifying, understanding, and investigating the causes of error. Therefore, the following hypothesis is proposed:

$\mathrm{H}_{1}$ : The auditor's work experience has a significant positive effect on the audit quality.

The auditor's professional competence is the auditor's ability to apply the knowledge and experience gained during the audit so that the auditor can perform the audit work accurately and objectively [8]. A higher level of competency leads to a higher quality auditor. The experience and skill variables selected to represent the competency variable, have a negative relationship with the execution time and completion of the operation, then the following hypothesis can be presented [9].

$\mathrm{H}_{2}$ : The competence of the auditing profession has a significant positive effect on the quality of the audit. According to Robbins, motivation is a process of producing intensity, objectivity and individual insistence in trying to achieve goals. Ardini divided motivation into two parts: positive motivations and negative motivations. Positive motivation is the process of trying to influence the others to do what we want and as a result we are more likely to be rewarded. Negative motivation is the process of trying to influence people to do what we want, but the basic technique used is power. A positive correlation among the types of auditors' personalities, includes the external and internal control center, the ethical culture in the audit firm, and group norms and audit quality [11]. Many issues related to the quality of international standards are covered by clear and expeditious terms, however this phrase cannot be derived from the field of audit quality ethics. One of the important reasons lies in the fact that the business environment is very dynamic and business and tradition activities differ from one country to another. Since the standard process requires the continuous repetition of a standard goal for a specific period of time, it is impossible the standard effective respond to the changing pressures that quality auditors face. The positive and significant 
effect of time budget pressure on reporting is less than real time. In addition, the results show a significant diverse effect of ethics on time budget pressure [12]. Therefore, the following hypothesis can be expressed. $\mathrm{H}_{3}$ : The auditor's motivation has a positive and important effect on the quality of the audit. The hypothesis 3 has four parts:

$\mathrm{H}_{1}$. Character type has a positive and significant effect on the auditor's motivation.

$\mathrm{H}_{2}$. Internal and external control has a significant effect on the auditor's motivation.

$\mathrm{H}_{3}$. Auditing norms have a positive and significant effect on the auditor's motivation.

$\mathrm{H}_{4}$. Ethics culture affects the company and the auditor's motivation.

To Tetclock, accountability is a form of psychological motivation that makes a person feel responsible for all actions in the environment. In the face of contradictions with internal findings in the audit process, responsibility and accountability for the audit work is performed and time pressure leads to concerns about reducing the reputation and increasing the likelihood of confidentiality of audit evidence [13]. Therefore, the following hypothesis can be expressed.

$\mathrm{H}_{4}$ : Accountability has a significant positive effect on audit quality.

Sukriah shows that a person is objectivist when in the audit process the auditor can get rid of all differences and be able to express the statements according to the facts. Objectivism and delay in internal audit are inversely related, but the size of internal audit is not significantly related to this variable [10]. Therefore, the following hypothesis can be expressed.

$\mathrm{H}_{5}$. The auditor's objectivism has a significant positive effect on the audit quality.

According to the formulations of the above hypotheses, the study framework is in the form of figure 1.

\section{Method}

This is an experimental study based on studies on audit quality and related results. It is a descriptivecommunication study based on data collection. Data collection methods were applied using survey questionnaires of independent variables of work experience, professional competence, motivation, accountability and the auditors' impartiality and audit quality variables. After data collection, the results are tested by SPSS and EViews software. In this study, regression analysis was used to investigate the relationship between variables and the proposed model to explain the dependent variable. Data was collected by a questionnaire. The statistical population includes all listed Iranian companies in 2016. The study was conducted in the auditing offices of public accounting companies.

In this study, 200 questionnaires were distributed among auditors of public accounting companies. A total of 80 questionnaires $(40 \%)$ had erroneous frequency and 18 cases $(9 \%)$ were incomplete that did not have the qualify for the study. As a result, 102 questionnaires $(51 \%)$ were usable.

The regression used to test the hypothesis is as follows.

$$
\begin{aligned}
\mathrm{AQ}= & \alpha_{0}+\beta_{1} \mathrm{WE}+\beta_{2} \mathrm{PC}+\beta_{3} \mathrm{CT}+\beta_{4} \mathrm{IEC}+\beta_{5} \mathrm{AN} \\
& +\beta_{6} \mathrm{EC}+\beta_{7} \mathrm{AC}+\beta_{8} \mathrm{OB}+\varepsilon_{0}
\end{aligned}
$$

In which, the $\mathrm{AQ}$ is the audit quality, WE is the work experience, $\mathrm{PC}$ is the professional competence, and MO is the motivation of auditor, which consists of three parts: CT (character type), IEC (internal and external control), AN (auditing norms), EC (ethical culture), AC (auditor's accountability), OB (auditor's objectivism), and $\varepsilon_{0}$ is the other cases.

\section{Define Variables}

Audit quality: One of the most common definitions of audit quality is the definition given by de Angelo. He defines audit quality as a "market assessment (inference)" of the auditor's ability to detect and report major distortions of an employer's financial and accounting system. Whether significant cases of major misstatement are detected, depends on the auditor's professional competence, and whether the auditor reports such cases, depends on the auditor's independence. Hajiha's definition of real audit quality is based on customers' perceptions or market understanding of audit quality. The use of this definition is based on the fundamental hypothesis that the interpretation of audit quality reflects the true quality of the audit.

Auditor's work experience: The auditor's work experience leads to increased independence and in turn increases quality. On the other hand, the knowledge and expertise of the customer is an important part of the experience that leads to improving the audit quality. Increasing knowledge and experience, the auditor is able to detect more deviations and errors in the audit process.

Auditor's professional competence: The auditor professional competence is the basis of the individual's observable behaviors are determined. In addition, better regulatory performance and competencies required for normal operations are not considered. The higher the professional competence, the higher the audit quality. Professional auditors must perform professional services with accuracy and competence. They must always maintain a high level of knowledge and skills in line with the latest standards and regulations. 
Auditor's Motivation: According to the theory of planned behavior, the auditor's motivation for individual and organizational factors. The auditor's behavior reflects his personality traits [17]. Personality According to other planned behavior theory, environmental factors can also affect motivation. According to planned behavior theory, environmental factors can also affect motivation in addition to the personality traits. Most studies have focused on the relationship between individual characteristics and the impact of other factors such as organizational factors and groups has not been studied. In this study, the effect of three individual, organizational and group factors such as auditor's character, ethical culture in the company and group norms on auditors' motivation are investigated to report deviations and errors as audit quality. The theory of planned behavior is an important theory in psychology that explains the basic mechanism for accepting behavior. According to this theory, when a person is motivated to perform a behavior, the behavior is more likely to occur. There are two general categories of motivations for doing a behavior: individual factors and environmental factors. Individual factors include internal and external control and character. Environmental factors are the ethical culture in the company and group auditing norms.

Character: Psychological researchers have found that people with different characters deal with ethical issues in different ways [18]. In fact, most people with personality type $\mathrm{A}$ are more committed to their tasks than people with type $\mathrm{B}$, and make more efforts to achieve organizational goals without having to contract immoral behaviors [19].

Internal and external control: According to the theory of planned behavior, the more people have control over their behavior, the more likely they are to do their job. The level of control that people have over their behavior and the outcome of their work can be determined using internal and external control factors.

Auditing norms: According to the theory of planned behavior, auditing norm is another factor in the audit firm environment that will affect the auditor's behavior. The audit team norms are the group beliefs in the ethical behaviors that they are expected to follow. reporting errors and fraud is divided into two groups of

Ethical culture in the company: When people are under pressure from the environment to adhere to ethical behavior, ethical behavior is more likely to be observed. This pressure will be exerted by the ethical culture in auditing firms [20] recognized that ethical culture in the environment plays an important role in motivating auditors to encourage ethical behavior.

Auditor Accountability: Accountability for audit work performed and time pressures raise concerns about reputational degradation and lead to concealment of evidence that contradicts decisions based on previous results. Conducting an experimental project, auditors address concerns about reputational decline due to finding conflicting evidence and the possibility of concealing such evidence.

Auditor Objectivism: An independent auditor must be transparent, honest, and sincere in his/her professional work. The independent auditor should be impartial and should not incorporate prejudice. An independent auditor should maintain objectivism and avoid anything that could conflict with his/her honesty and objectivism. Avoidance of inconsistencies that may appear in practice and the objectivism of auditors in conducting audits are essential to maintain the credibility. Maintaining objectivism involves evaluating relationships with the unit under audit and other departments, and is considered a public responsibility for the auditor.

\section{Results}

\section{Descriptive Statistics}

Once the descriptive data has been collected for research, first it must be organized and summarized in a way that is significantly comprehensible. Therefore, descriptive statistical methods are recommended. Often the most useful and also the first step in organizing data is to sort the data based on a logical criterion and then extract the central parameters, scattering and, if necessary, calculate the correlation between two data sets and use more advanced analysis such as regression and forecasting (Table 1).

Table 1

Descriptive statistics

\begin{tabular}{llllcclll}
\hline Variable & Mean & Median & Std. deviation & Skewness & Kurtosis & Minimum & Maximum & Sum \\
\hline AQ & 3.98 & 4 & 0.933 & -0.632 & -0.102 & 1 & 5 & 406 \\
WE & 2.686 & 2 & 1.6708 & 0.356 & -1.577 & 1 & 5 & 274 \\
PC & 3.8393 & 3.89 & 0.47323 & -0.412 & 0.787 & 2.22 & 4.89 & 391.61 \\
CT & 0.627 & 1 & 0.4859 & -0.535 & -1.748 & 0.00 & 1 & 64 \\
IEC & 0.431 & 0.00 & 0.4977 & 0.281 & -1.96 & 0.00 & 1 & 44 \\
AN & 3.5221 & 3.6 & 0.46355 & -0.162 & 0.022 & 2.33 & 4.6 & 359.25 \\
EC & 3.1889 & 3.2 & 0.38281 & 0.78 & 3.335 & 2.25 & 4.93 & 325.27 \\
AC & 0.9098 & 1 & 0.12767 & -1.787 & 3.376 & 0.43 & 1 & 92.8 \\
OB & 0.814 & 1 & 0.3913 & -1.636 & 0.689 & 0.00 & 1 & 83 \\
\hline
\end{tabular}


In general, if the skewness and kurtosis are in the range $(2,2)$, the data are normally distributed. Statistical data it can be inferred from the standard deviation. Elongation of ethical independent variables in the company and the accountability of auditors are not the norm. The other variables have normal skewness and kurtosis.

After reviewing the normal procedure or skewing the data distribution, the Shapiro-Wilk test or Kolmogorov-Smirnov test is used to ensure that the data is normal. Once analyzing data normality, it is assumed that the data is normally explained with an error rate of 0.05 . Therefore, if the test statistic is greater than or equal to 0.05 , then there is no reason to reject the null hypothesis that the data is normal. In other words, the data are normally distributed (Table 2).

Table 2

Normality of tests

\begin{tabular}{llllll}
\hline Variable & \multicolumn{2}{c}{ Kolmogorov-Smirnov ${ }^{b}$} & & \multicolumn{2}{c}{ Shapiro-Wilk } \\
\cline { 2 - 3 } \cline { 6 - 7 } & Statistic & Sig. & & Statistic & Sig. \\
\hline EC & 0.063 & $0.200^{\mathrm{a}}$ & & 0.955 & 0.002 \\
AC & 0.27 & 0.000 & & 0.737 & 0.000 \\
\hline
\end{tabular}

a: This bottom line is true significance.

b: Modify the significance of Lilliefors

Table 3

Descriptive statistics

\begin{tabular}{lllllllll}
\hline Variable & Mean & Median & Std. deviation & Skewness & Kurtosis & Minimum & Maximum & Sum \\
\hline $\mathrm{AC}$ & .0103 & .8700 & 1.07038 & -.978 & -.256 & -2.53 & .87 & 1.05 \\
\hline
\end{tabular}

The independent variable of accountability is normalized by the logarithmic method.

Table 4

Correlation

\begin{tabular}{|c|c|c|c|c|c|c|c|c|c|}
\hline Variable & $A Q$ & WE & $P C$ & CT & IEC & AN & EC & $A C$ & $\mathrm{OB}$ \\
\hline$A Q$ & 1 & & & & & & & & \\
\hline WE & 0.396054 & 1 & & & & & & & \\
\hline PC & 0.335588 & 0.24691 & 1 & & & & & & \\
\hline CT & -0.05994 & 0.049741 & -0.15744 & 1 & & & & & \\
\hline IEC & 0.039707 & 0.140537 & 0.030275 & -0.10677 & 1 & & & & \\
\hline AN & 0.197614 & -0.00338 & 0.27017 & 0.036849 & -0.1734 & 1 & & & \\
\hline EC & 0.209465 & 0.097607 & 0.272438 & 0.061165 & -0.32648 & 0.380244 & 1 & & \\
\hline$A C$ & 0.271888 & -0.05891 & 0.188419 & -0.09003 & -0.18925 & 0.152394 & 0.128134 & 1 & \\
\hline OB & 0.261066 & -0.05999 & -0.15738 & -0.10825 & 0.00997 & 0.001044 & 0.027071 & 0.153332 & 1 \\
\hline
\end{tabular}

Table 5

Model summary

\begin{tabular}{lllll}
\hline Model & $R$ & $R$-square & Adjusted $R$-square & Std. error of the estimate \\
\hline 1 & $0.612^{\text {s }}$ & 0.375 & 0.321 & 0.769 \\
\hline
\end{tabular}

a: Predictors (fixed), EC PC, IEC, AC, CT, WE, AN, OB

b: Dependent variable: AQ 


\section{Correlations}

If the variables are not independent of each other, they are definitely not correlated. Correlation coefficient is a statistical tool used to measure the power or degree of linear relationship between two variables. The most famous correlation coefficient is Pearson correlation. This index ranges from -1 to +1 (Table 4).

According to this table, a higher correlation coefficient of a variable means a higher correlation. According to Table 2, the correlation is inverse and complete. Yield is between -1 and +1 .

Detection Coefficient
The $\mathrm{R}$ value indicates that there is a correlation between independent and dependent variables. A R value indicates that a higher percentage of the audit quality variable is explained by 5 variables (Table 5). The value of $\mathrm{R}$ is 0.612 and indicates a strong correlation between the dependent variable (audit quality) and independent variables (work experience, professional competence, motivation, accountability and objectivism). The $\mathrm{R}$ value of 0.321 indicates that $32.1 \%$ of the quality variable is explained by five independent variables, while the other $67.5 \%$ is explained by the other variables out of the model.

Scattered Diagrams

Dependent Variable: AQ

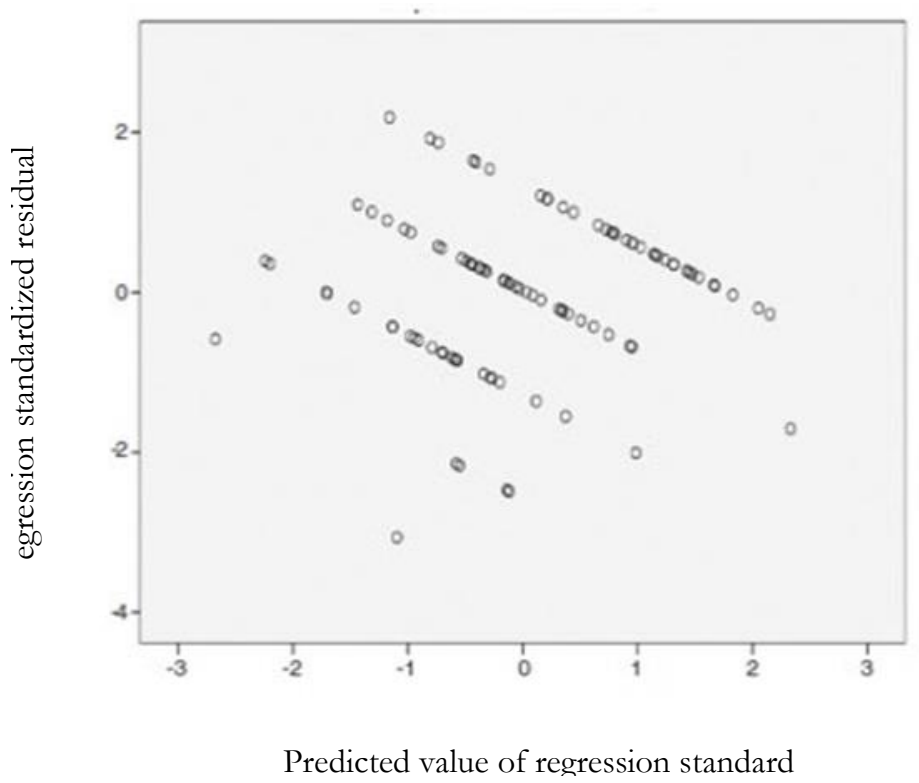

Figure 2. Heterogeneity test result

Simultaneous Significance Test Results

According to the results of the $\mathrm{F}$ test, the value of $\mathrm{F}$ is less than 0.05. The results show how much of the regression model can be used to predict audit quality (Table 6).

According to the $\mathrm{F}$ test, the value of $\mathrm{F}$ obtained is 6.973, with a significance value of 0.0001 (less than
0.5). The results show that the regression model can be used to predict audit quality. Work experience, professional competence, motivation and objectivism simultaneously have an important effect on the audit quality. The test result is consistent with the studies by Malekian and de Angelo.

Table 6

ANOVA

\begin{tabular}{lllrll}
\hline Model & & Sum of squares & df & Mean square & $F$ \\
\hline 1 & Regression & 32.979 & 8 & 4.122 & 6.973 \\
& Residual & 54.982 & 93 & 0.591 & $0.000^{\text {b }}$ \\
& Total & 87.961 & 101 & & \\
\hline
\end{tabular}

a: dependent variable: $\mathrm{AQ}$

b: Predictors (fixed), EC PC, IEC, AC, CT, WE, AN, OB 
Minor Significance Test Results

According to Table 7, work experience has a regression coefficient of 0.21 and a value of t equal to 4.14 with a significance level of 0.00 (less than 0.05), which indicates that $\mathrm{H}_{1}$ is acceptable, and the work experience has a significant effect on the audit quality. The result of this research is in accordance with the studies done by Kharismatuti and Robbins, but the results are not consistent with the study by Efendy. Professional competency has a regression coefficient equal to 0.412 ; $\mathrm{t}$ value is 2.189 and the significance value is 0.031 (less than 0.05), which means that $\mathrm{H}_{2}$ is acceptable. As a result, the professional competence has an effect on audit quality. The result of this research is in accordance with the research 1,3,11, but in contradiction with the results of the studies by Robbins and Malekian.

Table 2

\begin{tabular}{|c|c|c|c|c|c|c|}
\hline \multicolumn{2}{|c|}{ Model } & \multicolumn{2}{|c|}{ Unstandardized coefficients } & \multirow{2}{*}{$\begin{array}{l}\text { Standardized coefficients } \\
\text { Beta }\end{array}$} & \multirow[t]{2}{*}{$t$} & \multirow[t]{2}{*}{ Sig. } \\
\hline & & $B$ & Std. error & & & \\
\hline \multirow[t]{9}{*}{1} & (Constant) & 0.066 & 0.942 & & 0.07 & 0.945 \\
\hline & WE & 0.201 & 0.048 & 0.359 & 4.14 & 0.00 \\
\hline & PC & 0.412 & 0.188 & 0.209 & 2.189 & 0.031 \\
\hline & CT & 0.004 & 0.164 & 0.002 & 0.022 & 0.982 \\
\hline & IEC & 0.105 & 0.17 & 0.056 & 0.618 & 0.538 \\
\hline & AN & 0.194 & 0.184 & 0.097 & 1.058 & 0.293 \\
\hline & EC & 0.161 & 0.234 & 0.066 & 0.688 & 0.493 \\
\hline & $A C$ & 0.173 & 0.076 & 0.198 & 2.264 & 0.026 \\
\hline & OB & 0.675 & 0.204 & 0.283 & 3.301 & 0.001 \\
\hline
\end{tabular}

a: dependent variable: $\mathrm{AQ}$

Motivation has regression coefficients according to four independent variables: Character, internal and external control, auditing norms and ethical culture in the company. Regression coefficients equal to 0.194 , $0.105,0.004$ and $0.161 . \mathrm{t}$ values are $1.058,0.618,0.022$ and 0.688 with the significance levels of $0.293,0.538$, 0.982 and 0.493 which are more than 0.05 . Then $\mathrm{H}_{3}$ is rejected which means the motivation has no effect on the audit quality. This is in accordance with the results of the studies by Singgih and Ardini, but the results are not consistent with the studies by Malekian, Sweeney and Kharismatuti.

Accountability has a regression coefficient equal to 0.173 and its $t$ value is 2.264 with a significance level of 0.026 (less than 0.05); Then $\mathrm{H}_{4}$ is acceptable, which means that accountability is effective on the audit quality. This is in accordance with the results of the studies done by Arianti and Bustami, but the results are not consistent with the study by Ardini.

Objectivism has a regression coefficient equal to 0.204 and its $t$ value is 3.301 with a significance level of 0.001 (less than 0.05); Then $\mathrm{H}_{5}$ is acceptable, which means that objectivism is effective on the audit quality. This is in accordance with the results of the studies by Robbins and Arianti, but the results are not consistent with the study by Aghaei.

The multiple regression equation of this research is:

\footnotetext{
$\mathrm{AQ}=0.066+0.201 \mathrm{WE}+0.412 \mathrm{PC}+0.004 \mathrm{CT}+0.105 \mathrm{IEC}$ $+0.194 \mathrm{AN}+0.161 \mathrm{EC}+0.173 \mathrm{AC}+0.675 \mathrm{OB}$
}

\section{Conclusion}

The first hypothesis was accepted. Therefore, people with more work experience had higher the audit quality, because most of people who filled out the survey form had work experience and this led them to better audit quality.

The second hypothesis was accepted. This means that the audit quality was affected by professional competence. Increased professional competence indicates that the auditor had intense curiosity, the broad thinking, power to do indefinite and team work. The auditor also has the ability to perform an analytical review that focuses on the organizational theory of auditing and the public sector as well as accounting. The auditor also specializes in computer use and understanding statistics. Competency is essential for auditing. Competency requires the auditor to improve the expertise required to ensure professional services. The auditor must also maintain and improve his / her competencies and receive professional training so that the clients can receive the services they deserve professionally.

Hypothesis 3 (the auditor's motivation) was rejected. This means that there was no significant relationship between the auditor's motivations and the audit quality. Considering that auditing was measured by four variables of character, internal and external control, 
auditing norms and ethical culture in the company, all them were significantly related to the audit quality.

means that the auditor can perform the audit work efficiently in a timely manner so that the work is carefully reviewed by observer and he/she is accountable to the employer. Auditors also perform audit work on a diligent basis, using mental and physical force, thus increasing the quality of audit. Accountability is very important for the auditor as a factor that affects the quality of the audit. Accuracy and sharpness play an important role in the auditor's accountability in doing things.

Hypothesis 4 was accepted which means that objectivism affected the audit quality. An increase in objectivism indicates that an auditor who can operate without pressure or impact from a particular department rejects audits that are affiliated with specific groups. Objectivism can be achieved on the basis of the willingness to audit by considering the standards and the actual situation.

One of the constraints of this study included the use of only one source (questionnaire) to collect data; This means that the results cannot be generalized. Since the data is collected through a questionnaire, the results depended on the honesty and unity of the respondents. According to the previous researches, the question of reporting detected errors can only be obtained by asking them.

In this study, only the opinions of independent auditors were examined and government and internal auditors were not studied. This constraint prevents the results from being extended to other sections and levels.

Questionnaires were distributed during the busy season. Some auditors did not have enough time to fill out the questionnaires. This should not be done when looking for appropriate answers to the questionnaires. The value $\mathrm{R}^{2}$ was 0.312 . This indicates that $67.9 \%$ is explained by other variables not studied in this study. Researchers should consider other independent variables such as independence, integrity, time pressure, budget, reward, and tenure.

\section{References}

1. Ramadhanis S. Pengaruh kompetensi, kemandiriandan motivasi terhadap kualitas audit di inspektorat (The influence of competence, independence and motivation to audit quality at inspectorate). E-Jurnal Binar Akuntansi. 2012; 2(1): 76-83. Retrieved from https://onlinejournal.unja.ac.id/index.php/JBA/article/view/1311

2. Singgih EM, Bawono IR. Pengaruh independensi, pengalaman, due professional care dan akuntabilitas terhadapkualitas audit. In Paper Presented at the Simposium NasionalAkuntansi XIII (SNA13), Universitas Jenderal Soedirman. 2010.
Hypothesis 4 was accepted, which means the accountability affected the audit quality. Accountability 3. Ardini L. Pengaruh kompetensi, independensi, akuntabilitasdan motivasi terhadap kualitas audit (The influence of competence, independence, accountability and motivation on quality audit). Majalah Econ. 2010; 20(3): 329-349.

4. Ilamiyati F, Suhardjo Y. Pengaruh akuntabilitas dankompetensi auditor terhadap kualitas audit. (The effect of accountability and auditor competence on audit quality). Juraksi. 2012; 1(1): 43-56.

5. Saripudin, Herawaty N, Rahayu. Pengaruh independensi, pengalaman, due professional care dan akuntabilitasterhadap kualitas audit (Influence of independence, experience, due professional care and accountability to audit quality) E-Jurnal Binar Akuntansi. 2012; 1(1): 4-13. Retrieved from https://online journal.unja.ac.id/index.php/JBA/article/view/725

6. Sukriah I, Akram, Inapty BA. Pengaruh pengalamankerja, independensi, obyektifitas, integritas dan kompetensiterhadap kualitas hasil pemeriksaan. In Paper Presented at the Simposium Nasional Akuntansi XII (SNA12), Universitas Sriwijaya. 2009.

7. Samsi N, Riduwan A, Suryono B. Pengaruh pengalamankerja, independensi, dan kompetensi terhadap kualitas hasilpemeriksaan dengan kepatuhan etika auditor sebagai variabelpemoderasi (The effect of work experience, independence and competence on audit quality: Auditor ethics as moderating vari-able). $J$ Ilmu Riset Akuntansi. 2013; 1(12): 207-226.

8. Carolita MK, Rahardjo SN. Pengaruh penga lamankerja, independensi, objektifitas, integritas, kompetensi, da nkomitmen organisasi terhadap kualitas hasil audit (Effect of workexperience, independence, objectivity, integrity, competence and organizational commitment on the quality of audit results). Diponegoro J Account. 2012; 1(2): 1-11.

9. Rafiee A, Karimian M, Mahmoudi A, Haghighi Y. Internal auditor competence impact on the implementation of the independent audit. In Paper Presented at the $11^{\text {th }}$ National Conference of Accounting in Iran. 2013.

10. Robbins SP, Judge TA. Organizational behavior. NewJersey: Prentice Hall. 2009.

11. Aghaei A, Ahmadi N. Investigating the effect of auditor's personality characteristics, ethical culture in the audit institution, and audit's norms on the quality of audit work. In Paper Presented at the National Accounting Conference in Iran. 2015.

12. Malekian E, Tavakolnia E. The effect of ethical culture under budget pressure on audit quality time. Audit: Theor Pract. 2014; 1(1): 21-47.

13. Barzideh F, Kheirollahi M. Accountability, time pressure and suppression of audit evidence. J Audit Sci. 2012; 11(45): 4-27. 
14. Hajiha Z, Rafiee R. The impact on the timeliness of quality internal audit function independent audit report. Res Financ Account Audit. 2014; 24(6): 121-137.

16. Krishnan J, Schauer PC. The differentiation of quality among auditors: Evidence from the not-forprofit sector. Audit: J Pract Theor. 2000; 19(2): 9-25.

17. Paino H, Ismail Z, Smith M. Dysfunctional audit behavior: An exploratory study in Malaysia. Asia Rev Account. 2010; 18(2): 162-173.

18. Fisher RT. Role stress, the type A behavior pattern, and external auditor job satisfaction and performance. Behav Res Account. 2001; 13(1): 143-170.

19. Mohd Nor M. Auditor stress: Antecedents and relationships to audit quality (Doctoral dissertation). Perth, Australia: Edith Cowan University. 2011.

20. Sweeney JT, Roberts RW. Cognitive moral development and auditor independence. Account Organ Soc. 1997; 22(3/4): 337-352.

21. Suyono E. The effects of independence, experience, and accountability to the audit quality. Purwokerto, Indonesia: University of Jenderal Sudirman. 2012; https://www.wbiconpro.com/110Eko.pdf

22. Kharismatuti N, Hadiprajitno PB. Pengaruh kompetensidan independensi terhadap kualitas audit dengan etika auditorsebagai variabel moderasi. (The influence of competence and independence on audit quality with auditor ethics as a moderation variable). Diponegoro J Account. 2012; 1(1): 1-10.

23. Efendy MT. Effect of competence, independence, and motivation on audit quality apparatus regional
15. de Angelo LE. Auditor size and audit quality. $J$ Account Econ. 1981; 3(3): 183-199

financial supervisory inspectorate. Pengaruh kompetensi, indepen-densi, dan motivasi terhadap kualitas audit aparat inspek-torat dalam pengawasan keuangan daerah (Master's thesis). Semarang, Indonesia: Diponegoro University. 2010; http://eprints.undip.ac.id/24634/1/Muh.TaufiqEfend y.pdf

24. Rosnidah I, Rawi, Kamarudin. Analisis dampak motivasidan profesionalisme terhadap kualitas audit aparat inspektoratdalam pengawasan keuangan daerah (Analysis of the impact of motivation and professionalism on the audit quality of theinspectorate apparatus in the supervision of regional finances). Pekbis J. 2011; 3(2): 456-466.

25. Arianti KP, Sujana E, Putra I. Pengaruh integri-tas, obyektivitas, dan akuntabilitas terhadap kualitas auditdi pemerintah daerah (Influence of integrity, objectivity, and accountability on quality audit in local government). E-Journal SI AK University of Ganesha Education Accounting Department SI. 2014; 2(1): https://ejournal.undiksha.ac.id/index.php/S1ak/article /view/2410/2087

26. Bustami A. The influence of independence, accountability and auditor professionalism on quality audit. Pengaruh inde-pendensi, akuntabilitas dan profesionalisme auditor terhadapkualitas audit (Master's thesis). Jakarta, Indonesia: Universitas Islam Syarif Hidayatullah. 2013.

\section{SJAMAO}

Copyright: (C) 2021 The Author(s); This is an open-access article distributed under the terms of the Creative Commons Attribution License (http://creativecommons.org/licenses/by/4.0), which permits unrestricted use, distribution, and reproduction in any medium, provided the original work is properly cited.

Citation: Roohbakhsh Z , Kazemzadeh F. Audit Quality Based on Auditor Features. SJAMAO, 2021; 3(4): 1-9. 